\title{
DEVELOPMENT OF A NOVEL ELECTROCHEMICAL METHOD FOR THE DETECTION OF INVERTASE ENZYME IN HONEY SAMPLES
}

\author{
Beáta Bóka - Judit Bajzát - Helga Szalontai
}

\section{Summary}

Invertase (a-glucosidase) is one of the most important honey enzymes; it hydrolyses sucrose into fructose and glucose during honey ripening process. Next to the basic honey ingredients (glucose, fructose, water), invertase activity is one of the main characterising parameter of honey: it can be used as indicator of aging andlor overheating, but it also may give information about adulteration.

Our aim was to develop a novel analytical method for the fast determination of invertase activity that can be used during quality control of honey samples. Our assay based on the application of an artificial substrate, namely p-nitrophenyl- $\alpha$-D-glucopyranoside. p-Nitrophenol produced by the enzyme reaction is detected by amperometric method which is much more sensitive than the traditional spectrophotometric determination.

Screen-printed carbon electrodes and a potentiostat were used for amperometric measurement. Our measuring system worked in flow injection system. The measuring parameters (polarization potential, pH etc.) were optimized. The applicability of the method was tested for detection of a-glucosidase enzyme activity.

Keywords: honey, enzymes, invertase activity, food analysis, food quality, electroanalytical detection, method development

JEL: Q10 


\section{Introduction}

Honey is a natural food product characterised by a complex composition. It composed mainly of carbohydrates (60-85\%) and water (12-23\%) (Machado De-Melo et al. 2018). Besides these main constituents it also contains about 200 substances in smaller amounts such as organic acids, minerals, vitamins, amino acids, proteins and several other bioactive substances (e.g. phenols and flavonoids) (Escuredo et al. 2013). The composition of honey depends mainly on the botanical and geographical origin of nectar and the honeybee species participated in honey production. It is also affected by weather conditions, honey processing and manipulation (Escuredo et al. 2014). Moreover, many expected changes in honey composition occur during storage due to different chemical reactions, including fermentation, oxidation and thermal processing (da Silva et al. 2016). These changes may have effect on food quality as well. Therefore, amount of certain honey components can be used as identity and quality parameters, and some of them can also indicate possible adulterations motivated by limited availability and high price of honey.

Invertase ( $\alpha$-glucosidase) enzyme - which activity is one of the honey quality indicators (Naila et al. 2018) - hydrolyses sucrose into fructose and glucose during honey ripening process. Invertase is the most sensitive honey enzyme to thermal process, therefore the invertase activity is the best quality parameter that can be used as indicator of aging and/or overheating. Moreover, it may give information about adulteration as well.

\section{Material and methods}

\section{Chemicals}

As invertase standard $\alpha$-glucosidase from Saccharomyces cerevisiae (EC 3.2.1.20, 125 $\mathrm{U} \mathrm{mg}^{-1}$ protein, Sigma-Aldrich) was used.

Glucose, fructose, sucrose, maltose, p-nitrophenyl- $\alpha$-D-glucopiranoside (pnf G, $\mathrm{C}_{12} \mathrm{H}_{15} \mathrm{NO}_{8}$ ) and paranitrophenol (pnf, $\mathrm{O}_{2} \mathrm{NC}_{6} \mathrm{H}_{4} \mathrm{OH}$ ) were purchased from VWR International LLC (Radnor, PA, USA).

Water purified with an ELGA Purelab Option DV 25 system (ELGA LabWater, Lane End, UK) was used.

All other chemicals were of analytical grade.

The working electrolyte used for amperometric measurement was $0.1 \mathrm{M}$ phosphate buffer (PBS).

Honey samples were purchased from a local shop, and were diluted to $1 \mathrm{~m} / \mathrm{V} \%$ concentration by the appropriate phosphate buffer solution. 
The stock solutions of pnf $\mathrm{G}(10 \mathrm{mM})$ and the carbohydrates $(25 \mathrm{mM})$ were freshly prepared every working day.

The pnf standard samples $(0.1$ and $0.01 \mathrm{mM})$ were diluted from the stock solution (10 mM) with PBS before the measurement.

\section{Apparatus for eletrochemical measurement}

Amperometric measurements were carried out in flow injection analysis system (FIA) using QuadStat 164 potentiostat and e-corder A/D converter (eDAQ Pty Ltd, Denistone East, Australia). Screen printed electrodes (Metrohm C110, with graphite working and counter electrodes) were applied in the flow-through cell (DropSens, Spain). Chart software (eDAQ Pty Ltd, Denistone East, Australia) was used for data acquisition and elaboration. The constant buffer flow was maintained by a Minipuls 4 peristaltic pump (Gilson S.A.S., Villiers le Bel, France). The sample was injected with a Rheodyne 7725i type (Rohnert Park, CA, USA) manual injector equipped with $20 \mu \mathrm{l}$ sample loop.

\section{Results}

Our novel amperometric method for invertase detection based on the application of an artificial substrate, namely p-nitrophenyl- $\alpha$-D-glucopyranoside (pnf $G$ ). Honey invertase such as $\alpha$-glucosidase from Saccharomyces cerevisiae can hydrolyse the $\alpha$-glucosidic linkage of pnf G. This enzyme reaction is shown on figure 1 . The reaction product $\mathrm{p}-\mathrm{Nitrophenol}(\mathrm{pnf})$ is a yellow, water-soluble, electroactive compound. It is traditionally measured spectrophotometrically at $405 \mathrm{~nm}$. Its alternative eletrochemical detection was reported more sensitive than the traditional spectrophotometry in case of an alkaline phosphatase assay (Fanjul-Bolado et al. 2006). The limit of detection (calculated as the concentration corresponding to three times the standard deviation of the estimate) was $2 \times 10^{-8} \mathrm{M}$ using amperometric detection in a flow-injection analysis system.

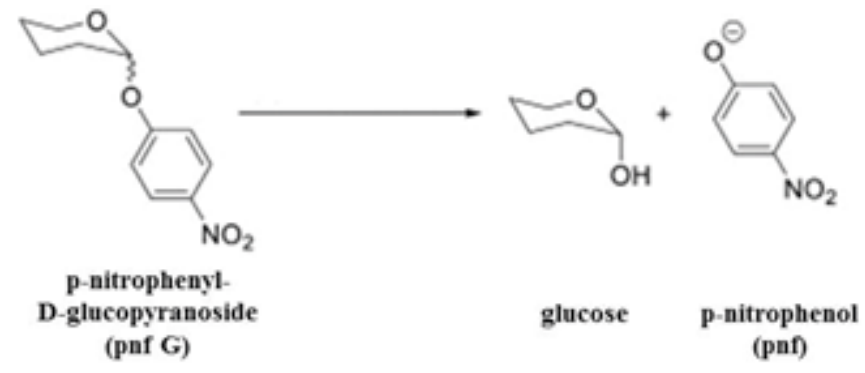

1. figure: The enzyme reaction 
The measuring parameters (polarization potential, $\mathrm{pH}$, etc.) were optimized. Flow rate of $1.0 \mathrm{ml} / \mathrm{min}$ was applied during the optimization studies. The signals of pnf G, pnf, carbohydrates present in honey (such as glucose, fructose and sucrose) and honey samples were studied as the function of polarization potential in the range from 100 to $1000 \mathrm{mV}$. The experiments were carried out at different $\mathrm{pHs}$ between $\mathrm{pH} 5.5$ and 7.0. The stock solutions of the artificial substrate (pnf G) and sugars studied gave no or neglible signals. In case of honey samples $(1 \mathrm{~m} / \mathrm{V} \%)$ small, but measurable signals could be detected at 400-1000 mV. While significant increased signal could be observed at 700-1000 mV polarizing potential when pnf standard samples $(0.01 \mathrm{mM})$ were measured. Therefore, the enzymatic conversion can cause signal increase at $900 \mathrm{mV}$ potential.

Studies with standard a-glucosidase enzyme were carried out to test the applicability of our detection method. Different amounts of enzyme were added to pnf $\mathrm{G}$ solutions $(0.001-1 \mathrm{mM})$ and the amperometric signals of the reaction mixtures were measured as the function of reaction time. Figure 2 shows a typical example.

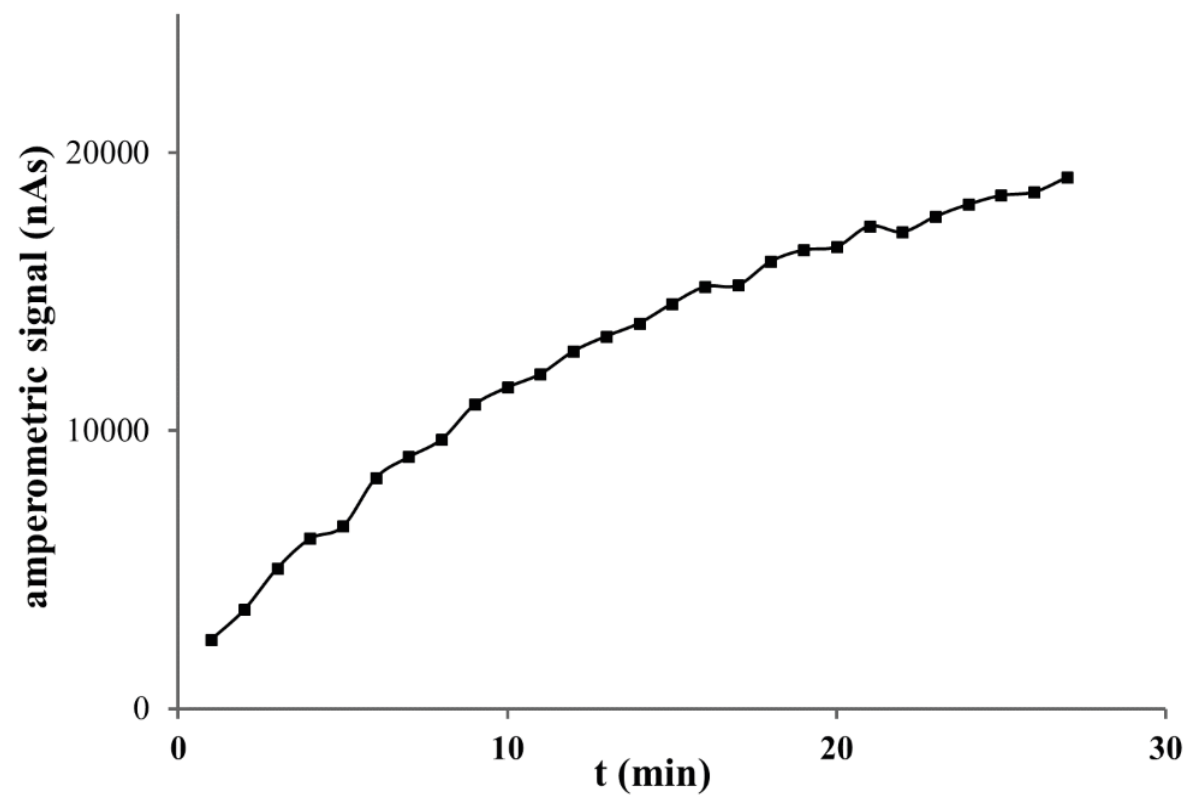

2.figure: Amperometric detection of $\alpha$-glucosidase enzyme

$0.01 \mathrm{mM}$ pnf G, $0.05 \mathrm{U} / \mathrm{ml}$ enzyme, $900 \mathrm{mV}, 1 \mathrm{ml} / \mathrm{min}$ phosphate buffer $(0.1$ $\mathrm{M} \mathrm{pH} \mathrm{7.0)}$

We can conclude that the novel method was suitable for the detection of $\alpha$-glucosidase enzyme activity. 


\section{Conclusions}

The final aim of our work is to develop a novel amperometric method for invertase ( $\alpha$-glucosidase) activity measurement, that can be used for quality control of honey samples. Our method based on the amperometric detection of the reaction product, pnf produced from an artificial substrate. The main measuring parameters were optimized. The best results could be obtained using phosphate buffer $\mathrm{pH} 7.0$ and $900 \mathrm{mV}$ polarization potential. Studies with standard $\alpha$-glucosidase enzyme were carried out. Our results demonstrated the suitability of our method for enzyme activity detection, although further development steps are required to achieve practical applicability in honey quality control.

\section{Acknowledgements:}

This work was supported by EFOP-3.6.1-16-2016-00001 ("Complex improvement of research capacities and services at Eszterházy Károly University").

\section{References}

[1.] Machado De-Melo A. A - de Almeida-Muradian L. B. - Sancho M. T. - Pascual-Mate A. (2018) Composition and properties of Apis mellifera honey: A review, Journal of Apicultural Research, 57, 5-37. https://doi.org/10.1080/00218839.2017.1338444

[2.] Escuredo O. - Míguez M. - Fernández-González M. -Seijo M.C. (2013) Nutritional value and antioxidant activity of honeys produced in a European Atlantic area, Food Chemistry, 138, 851-856. https://doi.org/10.1016/j.foodchem.2012.11.015

[3.] Escuredo O. - Dobre I. - Fernández-González M. - Seijo M. C. (2014) Contribution of botanical origin and sugar composition of honeys on the crystallization phenomenon, Food Chemistry, 149, 84-90. https://doi.org/10.1016/j.foodchem.2013.10.097

[4.] da Silva P.M. - Gauche C. - Gonzaga L. V. - Oliveira Costa A. C. - Fett R. (2016) Honey: Chemical composition, stability and authenticity, Food Chemistry, 196, 309-323. https://doi.org/10.1016/j.foodchem.2015.09.051 
[5.] Naila A. - Flint S.H. - Sulaiman A.Z. - Ajit A. - Weeds Z. (2018) Classical and novel approaches to the analysis of honey and detection of adulterants, Food Control, 90, 152-165.

https://doi.org/10.1016/j.foodcont.2018.02.027

[6.] Fanjul-Bolado P. - González-García M. B. - Costa-García A. (2006) Flow screen-printed amperometric detection of $\mathrm{p}$-nitrophenol in alkaline phosphatase-based assays, Analytical and Bioanalytical Chemistry, 385, 1202-1208.

https://doi.org/10.1007/s00216-006-0367-8

\section{Authors:}

Beáta Bóka PhD (supervisor)

college associate professor

Eszterházy Károly University

Food Science Institute

boka.beata@uni-eszterhazy.hu

Judit Bajzát (student)

Biology BSc

bajud98@gmail.com

\section{Helga Szalontai PhD}

research fellow

Eszterházy Károly University

Centre for Research and Development

Food and Wine Research Institute

szalontai.helga@uni-eszterhazy.hu 